\title{
Analisis Penggunaan Mobile Banking pada Generasi Milenial dengan Pendekatan Technology Acceptance Model (TAM)
}

\author{
Lutfi Rokhiyatul Mu'asiroh ${ }^{1}$, Darwanto ${ }^{2}$ \\ ${ }^{\mathbf{1}, 2}$ Prodi Ekonomi Islam Universitas Diponegoro \\ lutfirokhiyatulm@gmail.com
}

\begin{abstract}
This research aims to analyze the factors that can influence the millennial generation in using mobile banking. The approach in this research uses the Technology Acceptance Model (TAM) that has been developed by Davis (1989), namely benefits and convenience, and by adding three external variables, namely security, experience and compatibility. The research model was empirically tested using survey data from the millennial generation of students at Diponegoro University. The result of the analysis shows that all constructs in the TAM model namely benefits, convenience and the three external variable, security, experience and compatibility have a positive and significant effect on the use of mobile banking in the millennial generation partially or simultaneously. The implication of the results of this research is relevant for the millennial generation to be more confident on using mobile banking that can simplify their banking activities.

Keywords: benefits, compatibility, ease, experience, mobile banking, security, technology acceptance model (TAM)
\end{abstract}

\begin{abstract}
ABSTRAK
Penelitian ini bertujuan untuk menganalisis faktor - faktor yang dapat mempengaruhi generasi milenial dalam menggunakan mobile banking. Pendekatan dalam penelitian ini menggunakan model Technology Acceptance Model (TAM) yang telah dikembangkan oleh Davis (1989) yaitu manfaat dan kemudahan, serta dengan menambahkan tiga variabel ektsternal yaitu keamanan, pengalaman dan kompatibilitas. Model penelitian secara empiris diuji dengan menggunakan data survei generasi milenial pada mahasiswa di Universitas Diponegoro. Hasil analisis menunjukkan bahwa semua konstruk dalam model TAM yaitu manfaat dan kemudahan, serta tiga variabel eksternal yaitu keamanan, pengalaman dan kompatibilitas berpengaruh positif dan signifikan terhadap penggunaan mobile banking pada generasi milenial secara parsial maupun simultan. Implikasi dari hasil penelitian ini relevan bagi generasi milenial agar lebih yakin dengan menggunakan mobile banking dapat mempermudah aktivitas perbankannya.
\end{abstract}

Kata kunci: keamanan, kemudahan, kompatibilitas, manfaat, mobile banking, pengalaman, technology acceptance model (TAM) 


\section{A. PENDAHULUAN}

Keberhasilan sebuah organisasi dalam persaingan bisnis didukung dengan perkembangan teknologi yang semakin pesat dari tahun ke tahun. Kemajuan teknologi ini mempunyai efek yang sifatnya multiplier (pengganda), yang artinya kemajuan teknologi menyebabkan kemajuan di bidang lainnya. Salah satu bidang tersebut adalah bidang informasi dan komunikasi (Page, 2011). Perkembangan telepon seluler (HP) atau telekomunikasi nirkabel adalah salah satu perkembangan teknologi di bidang informasi dan komunikasi. Lembaga Riset Digital Marketing Emarketer memperkirakan pada tahun 2018 jumlah pengguna aktif smartphone di Indonesia lebih dari 100 juta orang (Suryani, 2013).

Gaya hidup masa kini berbanding lurus dengan pertumbuhan perkembangan teknologi. Salah satu yang mengikuti perkembangan teknologi informasi ini adalah perbankan. Hal ini diwujudkan dalam pengembangan sistem pelayanan terhadap nasabah dalam bentuk mobile banking. Aplikasi mobile banking merupakan sebuah fasilitas dari bank dalam era modern ini yang mengikuti perkembangan teknologi dan komunikasi. Saat ini kebanyakan mobile banking ditunjukkan melalui via SMS atau Mobile
Internet tetapi dapat juga menggunakan aplikasi (Pratiwi, 2012).

Dalam Islam, layanan mobile banking hukumnya boleh, menurut Mila (2014), transaksi mobile banking sesuai dengan kaidah fiqih "alhukmu, alasya'I fa'run an tashawurihi." Jadi, bertransaksi melalui mobile banking sama halnya dengan transaksi jual beli, yang mana bank sebagai penjual produk dan jasa sedangkan nasabah sebagai pembeli produk dan jasa. Dalam akad perjanjian mobile banking telah sesuai dengan syarat sahnya perjanjian dengan terpenuhinya rukun dan syarat akad (perjanjian).

Mobile Banking termasuk akad pelepasan hak (Intilaq) dengan atau tanpa ganti rugi disebut Akad Isqoth. Mengenai lafal ijab kabulnya yakni melalui tulisan diperbolehkan menurut jumhur ulama. Dan tidak terdapat unsur yang merugikan maupun yang menimbulkan kemadhorotan melainkan merupakan suatu hal yang mendatangkan banyak keuntungan. Pandangan hukum Islam terhadap mobile banking adalah bahwa transaksi mobile banking adalah suatu transaksi muamalah yang dibolehkan karena terdapat kemaslahatan yang besar bagi masyarakat khususnya nasabah pengguna layanan mobile banking (Trisni, 2018). 
Bila dilihat dari sistem serta prinsip operasionalnya, maka mobile banking menurut kaca mata fiqh kontemporer sebenarnya merupakan alat, media, metode teknis atau sarana yang dalam kaidah syariah bersifat fleksibel, dinamis, dan variabel. Hal ini termasuk dalam kategori persoalan teknis duniawi yang Rasullulah pasrahkan sepenuhnya selamanya dalam koridor Syariah kepada umat Islam untuk menguasai dan memanfaatkannya demi kemakmuran bersama selain itu dalam kaidah fiqih dikenal dengan kaidah yang berbunyi “Al-Ashl Fi al-Mu'amalati al-Ibahatu Illa an Yadulla dalil ala tahrimiha" (artinya hukum asal dalam semua bentuk muamalah adalah boleh dilakukan kecuali ada dalil yang mengharamkannya). Maka hukum bertransaksi menggunakan mobile banking adalah boleh berdasarkan prinsip maslahah karena kebutuhan akan kemajuan teknologi ini dengan berusaha memperbaiki dan menghindari kelemahan dan penyimpangan teknis maupun Syariah.

Salah satu faktor yang dapat mempengaruhi penggunaan teknologi informasi dan komunikasi adalah usia. Sebuah kategorisasi berbasis usia yang terkenal, biasanya digunakan terutama di bidang ekonomi, Generasi Milenial memiliki beberapa perilaku khas yang berbeda dari orang tua. Dibandingkan generasi sebelumnya, generasi milenial lebih akrab dengan komunikasi, media, dan teknologi digital. (Kumar, 2008).

$$
\text { Hasil dari Susenas } 2017
$$
menunjukkan bahwa memang generasi milenial lebih unggul dalam penggunaan telepon seluler (HP) / Nirkabel dibandingkan dengan generasi sebelumnya.

Gambar 1. Persentase Penduduk di Indonesia yang Menggunakan Telepon Seluler (HP) Menurut Generasi dan Daerah Tempat Tinggal, 2017

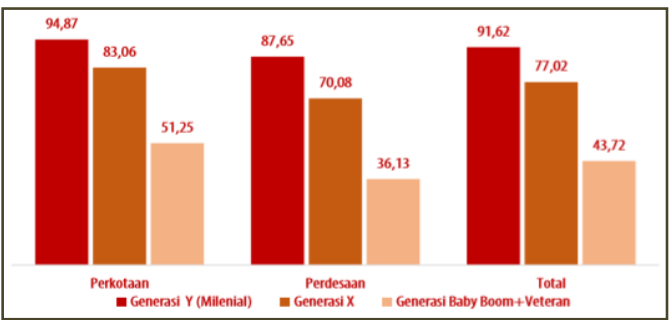

Sumber: Survei Sosial Ekonomi Nasional (Susenas), BPS

Antusiasme nasabah perbankan di Indonesia yang menggunakan layanan mobile banking terlihat pada situs BCA, Mandiri, dan BNI. Ketiga situs tersebut masuk dalam peringkat 100 top website Indonesia versi alexa.com (layanan pemeringkat situs).

Gambar 1. Persentase Pengguna Mobile Banking terhadap Total Nasabah 2015

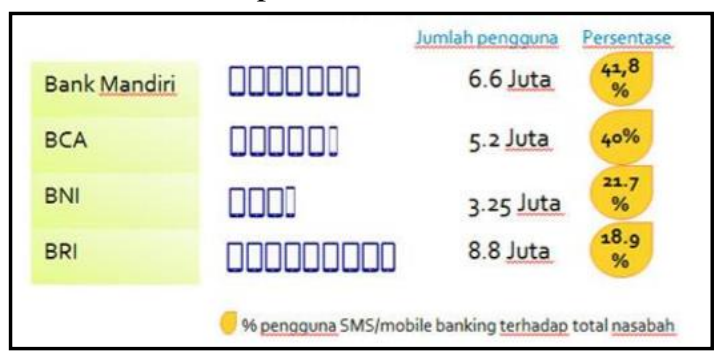

Sumber: Sharingvision.com 
Gambar 2 menunjukkan bahwa Bank Mandiri memiliki persentase pengguna mobile banking yang paling besar yaitu 41,8\% dengan 6,6 juta nasabah. Jumlah nasabah Bank Mandiri yang menggunakan mobile banking relatif lebih kecil dari total nasabah bank. Data tersebut menggambarkan bahwa nasabah yang menggunakan mobile banking di Indonesia yang dicerminkan dengan keempat bank tersebut relatif sedikit persentasenya, jika dibandingkan dengan keseluruhan nasabah bank. Pengguna mobile banking pada keempat bank tersebut tidak sampai setengah dari keseluruhan nasabah.

Penawaran layanan perbankan melalui mobile banking sebenarnya sudah banyak dilakukan di media-media elektronik maupun dengan menawarkan secara langsung kepada nasabah pada saat pembuatan rekening tabungan. Namun belum banyak nasabah yang menggunakan mobile banking dalam melakukan transaksi keuangannya (Hanif, 2017).

\section{Technology Acceptance Model} (TAM), yang pertama kali dicetuskan oleh Davis (1986) adalah sebuah pengembangan dan aplikasi dari Theory of Reasoned Action (TRA) yang dispesialisasikan untuk memodelkan penerimaan pemakai (user acceptance) terhadap sistem informasi (M. Davis, 1986). Model ini telah banyak digunakan untuk menguji penerimaan teknologi oleh pemakai sistem dalam berbagai macam konteks, salah satunya adalah penelitian dengan menggunakan teori TAM yang menunjukan bahwa keinginan individual untuk menggunakan suatu sistem baru ditentukan dengan dua keyakinan, yaitu: manfaat dan kemudahan penggunaan, didefinisi sebagai tingkat kepercayaan seseorang bahwa dengan menggunakan sistem tidak memerlukan usaha apapun (Venkatesh, 2000).

Penggunaan teknologi baru dipengaruhi oleh faktor lain yaitu keamanan, karena hal ini merupakan hal utama yang selalu dipertimbangkan nasabah dalam memutuskan untuk menggunakan layanan mobile banking. Beberapa nasabah engaan untuk menggunakan mobile banking, karena memiliki persepsi bahwa dengan melakukan transaksi secara online melalui mobile banking mudah terjadi penyalahgunaan dan memiliki resiko yang tinggi. Sehingga keamanan secara tidak langsung dapat menjamin kontinuitas bisnis, mengurangi resiko resiko yang terjadi (Syam, 1999).

TAM dikembangkan dengan menambahkan empat variabel eksternal 
untuk digunakan meneliti penerimaan pelanggan menggunakan teknologi internet. Empat variabel eksternal ini adalah experience (pengalaman), complexity (kompleksitas), gender (jenis kelamin) dan voluntariness (kesukarelaan) (Gardner, 2004). Dari ke empat variabel tersebut, menyatakan bahwa experience (pengalaman) berpengaruh positif signifikan terhadap perceived usefulness dan behavioral intention.

Mobile banking merupakan salah satu inovasi produk baru dari perbankan. Suatu produk dikatakan sukses ketika produk tersebut muncul dan diterima, hal tersebut tidak terlepas dari kekuatan sebuah inovasi produk. Inovasi produk menurut Kanagal (2015) dibutuhkan oleh perusahaan untuk mengatasi tekanan kompetitif, perubahan selera dan preferensi, siklus hidup produk. Tornatzky dan Klein (dalam Yeong et al. 2015 : 596) mengemukakan bahwa tiga karakteristik inovasi yaitu, keuntungan relatif, kompatibilitas dan kompleksitas. Pada penelitian Mohammadi (2015) ditemukan bahwa sistem kompatibilitas menjadi faktor utama yang mempengaruhi sikap pengguna terhadap penggunaan mobile banking.

\section{B. LANDASAN TEORI \\ 1. Teori Penerimaan Konsumen (Consumer Acceptance)}

Penerimaan konsumen terhadap suatu produk adalah salah satu hal yang penting, karena ketika konsumen menolak kehadiran produk di pasar, maka itu berarti merefleksikan kegagalan produk atau layanan dalam memenuhi kebutuhan, harapan, dan keinginan konsumen. Penerimaan konsumen didefinisikan oleh van den Bosch (dalam Vergragt, 2006) sebagai "a positive attitude of individuals towards an innovation and the intention to consume the product or service". Artinya, penerimaan konsumen merupakan sikap positif individu terhadap inovasi dan niat konsumen untuk mengkonsumsi produk atau layanan. Di mana niat konsumen untuk berperilaku tersebut dipengaruhi oleh sikap konsumen dan norma sosial.

\section{Teori Perilaku Konsumen}

Perilaku konsumen merupakan tindakan nyata individu atau organisasi yang dipengaruhi berbagai aspek internal dan eksternal guna mengarahkan mereka dalam memilih dan mengkonsumsi barang atau jasa yang diinginkan (Priambodo dan Prabawani, 2015). Kotler dan Keller (2009) mengatakan bahwa perilaku konsumen merupakan studi tentang bagaimana individu, kelompok, 
dan organisasi dalam memilih, membeli, menggunakan dan bagaimana barang, jasa, ide atau pengalaman untuk memuaskan kebutuhan dan keinginan mereka. Perilaku konsumen adalah kegiatan- kegiatan individu yang langsung terlibat dalam jasa, termasuk di dalamnya proses pengambilan keputusan.

\section{Mobile Banking}

Mobile banking adalah salah satu layanan inovatif yang ditawarkan oleh bank yang memungkinkan nasabah untuk melakukan transaksi perbankan melalui telepon seluler (HP). Melalui telepon seluler (HP) dan layanan mobile banking, transaksi perbankan yang biasanya dilakukan dengan manual, artinya kegiatan dilakukan nasabah dengan mendatangi bank secara langsung, sekarang dapat dilakukan tanpa harus mengunjungi bank, hanya dengan menggunakan telepon seluler (HP). Mobile banking bertujuan agar nasabah tidak ketinggalan jaman dalam menggunakan media elektronik yang sudah modern (Riswandi, 2005).

\section{Generasi Milenial}

Milenial (juga dikenal sebagai Generasi Y) adalah kelompok demografi setelah Generasi X (Gen-X). Tidak ada batas waktu yang pasti untuk awal dan akhir dari kelompok ini. Para ahli dan peneliti biasanya menggunakan awal 1980-an sebagai awal kelahiran kelompok ini dan pertengahan tahun 1990-an hingga awal 2000-an sebagai akhir kelahiran. Dibandingkan generasi sebelumnya, generasi milenial memiliki karakter unik, salah satu ciri utama generasi milenial ditandai oleh peningkatan penggunaan dan keakraban dengan komunikasi, media, dan teknologi digital. Karena dibesarkan oleh kemajuan teknologi, generasi milenial memiliki ciri-ciri kreatif, informatif, mempunyai passion dan produktif. Generasi ini merupakan generasi yang melibatkan teknologi dalam segala aspek kehidupan. Bukti nyata yang dapat diamati adalah hampir seluruh individu dalam generasi tersebut memilih menggunakan ponsel pintar (Center, 2017). Dengan menggunakan perangkat tersebut para millennials dapat menjadi individu yang lebih produktif dan efisien. Dengan demikian, generasi milenial merupakan objek dalam pemasaran di dunia digital.

\section{Technology Acceptance Model (TAM)}

Model yang dibangun untuk menganalisis dan memahami faktorfaktor yang mempengaruhi diterimanya penggunaan teknologi komputer ada beberapa, diantaranya yang tercatat dalam berbagai literatur dan referensi hasil riset dibidang teknologi informasi 
adalah seperti Theory of Reasoned Action (TRA), Theory of Planned Behaviour (TPB) dan Technology Acceptance Model (TAM). Model TAM diadopsi dan dikembangkan dari model TRA, yang diperkenalkan oleh Ajzen dan Fishbein (1980) dan diusulkan oleh Davis (1989), yaitu teori tindakan yang beralasan dengan satu premis bahwa reaksi dan persepsi seseorang terhadap sesuatu hal, akan menentukan sikap dan perilaku orang tersebut. Reaksi dan persepsi pengguna teknologi informasi akan mempengaruhi sikapnya dalam penerimaan terhadap teknologi tersebut. Salah satu faktor yang dapat mempengaruhinya adalah persepsi kegunaan dan kemudahan penggunaan sistem informasi sebagai suatu tindakan yang beralasan dalam konteks pengguna teknologi, sehingga alasan seseorang dalam melihat manfaat dan kemudahan penggunaan sistem informasi menjadikan tindakan/perilaku orang tersebut sebagai tolak ukur dalam penerimaan sebuah sistem.

\section{Konstruk-Konstruk Technology Acceptance Model (TAM)}

Davis (1986) menjelaskan bahwa tingkat penerimaan pengguna teknologi informasi ditentukan oleh beberapa konstruk, yaitu:

a. Persepsi Manfaat Penggunaan
Dalam Davis (1989) disebutkan bahwa orang percaya dengan menggunakan sistem tertentu akan meningkatkan kinerjanya. Hal ini dimaksudkan bahwa pengguna percaya bahwa dengan menggunakan sistem mobile banking tersebut akan meningkatkan kinerjanya. Hal ini menggambarkan manfaat sistem baru yang berkaitan dengan berbagai aspek. Dengan demikian, dalam persepsi kebermanfaatan ini membentuk suatu kepercayaan dalam pengambilan keputusan apakah jadi menggunakan sistem mobile banking atau tidak. Oleh karena itu, peneliti mengembangkan satu hipotesis :

Hipotesis 1 : Diduga manfaat berpengaruh positif signifikan terhadap penggunaan mobile banking pada generasi milenial.

b. Persepsi Kemudahan Penggunaan

Davis (1989) menyebutkan bahwa kemudahan artinya bebas dari kesulitan. Selanjutnya kemudahan dalam penggunaan didefinisikan sebagai sejauh mana seseorang percaya bahwa dengan menggunakan sistem tertentu akan bebas dari kesulitan. Jika diaplikasikan untuk sistem mobile banking, maka maksudnya nasabah meyakini bahwa sistem mobile banking mudah 
digunakan. Sehingga akan terbebas dari kesulitan dan tidak memerlukan usaha keras. Oleh karena itu, peneliti mengembangkan satu hipotesis :

Hipotesis 2 : Diduga kemudahan berpengaruh positif signifikan terhadap penggunaan mobile banking pada generasi milenial.

c. Sikap menggunakan teknologi

Sikap menggunakan teknologi dalam TAM dikonsepkan sebagai sikap terhadap penggunaan sistem yang berbentuk penerimaan atau penolakan sebagai dampak apabila seseorang menggunakan suatu teknologi dalam pekerjaannya (Davis, 1993).

\section{Keamanan}

Keamanan adalah suatu upaya untuk mengamankan aset informasi terhadap ancaman yang mungkin terjadi. Mobile banking harus memiliki sejumlah unsur penting mengenai keamanan. Menurut Eriksson dkk. (2008) terdapat tiga faktor keamanan yang harus mendapat perlindungan sistem keamanan mobile banking yaitu Aspek kerahasiaan, Aspek integritas dan Aspek ketersediaan. Sistem keamanan ini harus diimplementasikan dengan pengembangan layanan aplikasi perbankan dan yang terpenting yaitu bagaimana agar sistem layanan tersebut bersifat mudah digunakan dan mudah dioperasikan. Oleh karena itu, langkah awal dalam menggunakan mobile banking yaitu identifikasi resiko yang potensial terjadi ketika menggunakan aplikasi mobile banking tersebut. Oleh karena itu, peneliti mengembangkan satu hipotesis :

\section{Hipotesis 3 : Diduga keamanan} berpengaruh positif signifikan terhadap penggunaan mobile banking pada generasi milenial.

\section{Pengalaman}

Hasil temuan Thompson et al (1991) menunjukkan bahwa pengalaman berpengaruh terhadap penggunaan teknologi. Orang yang mempunyai pengalaman di bidang komputer mempunyai keahlian yang lebih tinggi dari orang yang tidak mempunyai pengalaman. Pemakai teknologi yang berpengalaman lebih sensitif terhadap besarnya hubungan komunikasi dalam penyampaian pelatihan daripada pemakai yang tidak berpengalaman. Pengalaman menggunakan teknologi akan mempengaruhi secara langsung ke penerimaan sistem. Pengalaman juga akan mempengaruhi penerimaan sistem secara tidak langsung lewat kepercayaan (beliefs) yaitu lewat kemudahaan penggunaan persepsian (perceived ease of use) dan kegunaan persepsian (perceived 
usefulness) (Indriantoro, 2000). Oleh karena itu, peneliti mengembangkan satu hipotesis :

Hipotesis 4 : Diduga pengalaman berpengaruh positif signifikan terhadap penggunaan mobile banking pada generasi milenial.

\section{Kompatibilitas}

Kompatibilitas adalah tingkat sesuainya inovasi dengan nilai dan pengalaman perorangan. Yeong et al. (2015) secara khusus mengungkapkan bahwa kompatibilitas memiliki hubungan positif terhadap minat penggunaan mobile banking. Kompatibilitas menunjukkan efek mediasi terkuat dalam menghubungkan ketersediaan layanan pelengkap terhadap minat untuk menggunakan mobile banking. Pada penelitian Mohammadi (2015) ditemukan bahwa sistem kompatibilitas menjadi faktor utama yang mempengaruhi sikap pengguna terhadap penggunaan mobile banking. Penelitian Mohammadi (2015) sesuai dengan penelitian sebelumnya oleh Hanafizadeh et al. (2014). Penelitian ini membuktikan bahwa kompatibilitas merupakan faktor terkuat yang mempengaruhi konsumen terhadap minat penggunaan. Oleh karena itu, peneliti mengembangkan satu hipotesis :
Hipotesis 5 : Diduga keamanan berpengaruh positif signifikan terhadap penggunaan mobile banking pada generasi milenial.

\section{METODE PENELITIAN}

Ridha (2017) variabel penelitian merupakan suatu atribut, nilai atau sifat dari objek individu atau kegiatan yang mempunyai banyak variasi tertentu antara satu variabel dengan lainnya yang telah ditentukan oleh peneliti untuk dipelajari informasi dan bisa ditarik kesimpulannya. Variabel dependen yang digunakan dalam penelitian ini yaitu penggunaan mobile banking pada generasi milenial. Sedangkan variabel independen pada penelitian ini adalah manfaat, kemudahan, keamanan, pengalaman dan kompatibilitas.

Penelitian ini menggunakan jenis data primer, yang diperoleh dari responden secara langsung melalui penyebaran kuesioner. Populasi dalam penelitian ini adalah generasi milenial dengan objek yaitu mahasiswa Universitas Diponegoro yang berstatus aktif pada tahun ajaran 2019/2020. Metode pengambilan sampel dari populasi menggunakan teknik non probability sampling, melalui pendekatan purposive sampling yaitu penentuan sampel penelitian dengan berdasarkan 
ciri-ciri atau kriteria tertentu. Gambaran umum/pola data dari penelitian ini menggunakan metode statistik deskriptif yaitu proses transformasi data penelitian dalam bentuk tabulasi. Sehingga mudah dipahami dan diinterpretasikan. Uji hipotesis dalam penelitian ini menggunakan teknik analisis regresi linear berganda dengan menggunakan aplikasi SPSS 26.0.

Analisis data yang digunakan adalah uji intrumen data berupa uji validitas dan uji reliabilitas. Uji asumsi klasik berupa uji normalitas, heteroskedastisitas, multikolinearitas. Metode analisis data yang digunakan untuk menguji hipotesis adalah menggunakan metode analisis regresi linear berganda, uji $\mathrm{T}$ dan uji $\mathrm{F}$. Teknik analisanya sebagai berikut :

$$
\begin{aligned}
\mathrm{Y}= & \mathrm{a}+\beta 1 \cdot \mathrm{X}_{1}+\beta 2 \cdot \mathrm{X}_{2}+\beta 3 \cdot \mathrm{X}_{3}+\beta 4 \cdot \mathrm{X}_{4} \\
& +\beta 5 \cdot \mathrm{X}_{5}+\mathrm{e}
\end{aligned}
$$

Keterangan :

$\mathrm{Y}=$ Penggunaan mobile banking

$\mathrm{a}=$ Konstanta

$\mathrm{X} 1=$ Variabel Manfaat

$\mathrm{X} 2$ = Variabel Kemudahan

X3 = Variabel Keamanan

X4 $=$ Variabel Pengalaman

X5 = Variabel Kompatibilitas

$\beta 1,2,3,4,5=$ Koefisien regresi manfaat, kemudahan, keamanan, pengalaman, kompatibilitas.

\section{PEMBAHASAN}

\section{Gambaran Umum Objek Penelitian}

Pengelompokan generasi dalam dunia kerja akan muncul mengikuti perkembangan manajemen sumber daya manusia. Generasi adalah suatu konstruksi sosial yang di dalamnya terdapat sekelompok orang yang memiliki kesamaan umur dan pengalaman historis yang sama (Mannheim, 1952).

Sejak adanya Teori Generasi (Generation Theory), di Indonesia muncul istilah traditionalist, baby boomers, generasi $\mathrm{X}, \mathrm{Y}, \mathrm{Z}$ dan alpha. Segala sesuatu terutama yang berhubungan dengan prilaku, gaya hidup, profesi, budaya yang sering dikaitkan dengan ciri-ciri dari generasi-generasi tersebut. Berikut merupakan pengelompokkan generasi di Indonesia menurut Shahreza (2017) yang dibuat berdasarkan rentan waktu setiap generasi yang disesuaikan dengan kejadiankejadian yang sangat berpengaruh kepada suatu generasi sesuai eranya :

\section{a. Traditionalist}

(1928-1945), dikarenakan masih baru adaptasi setelah masa penjajahan, teknologi informasi dan komunikasinya masih sangat minim. 
b. Baby Boomer (1946-1964), era ini merupakan masa awal pertumbuhan teknologi komunikasi dan informasi. Munculnya radio, TV, surat kabar, dan lain-lain.

c. Generasi X (1965-1976), generasi yang lahir pada tahuntahun awal dari perkembangan teknologi dan informasi seperti penggunaan $\mathrm{PC}$, video games, TV kabel dan internet.

d. Generasi Y (1977-1998), dikenal dengan sebutan generasi mellenial atau milenium. Generasi Y ini banyak menggunakan teknologi komunikasi instan seperti email, SMS, instant messanging dan media sosial seperti facebook, whatsapp, instagram dan twitter.

e. Generasi Z (1999-2012), generasi ini merupakan generasi yang paling muda yang baru memasuki angkatan kerja dan lebih banyak berhubungan sosial lewat dunia maya.

f. Generasi Alpha (2013-2025), generasi alpha sejak kecil sudah diperkenalkan dengan kemajuan teknologi.

\section{Gambaran Umum Responden}

Karakteristik responden digunakan oleh peneliti untuk memberikan informasi mengenai data demografi responden (fakultas, jenis kelamin, semester, usia dan lama menggunakan mobile banking). Responden penelitian ini adalah Mahasiswa Universitas Diponegoro yang berstatus aktif pada Tahun Ajaran 2019/2020. Ada pun jumlah responden dalam penelitian ini ditentukan sebanyak 100 orang. Pada penelitian ini diketahui bahwa responden sebagian besar mahasiswa dari Fakultas Ekonomika dan Bisnis berjenis kelamin perempuan dan dengan usia 22 tahun. Sedangkan dari sisi semester, dapat diketahui bahwa sebagian besar responden merupakan mahasiswa Universitas Diponegoro yang menempuh semester 9 dan menggunakan mobile banking selama $1-3$ tahun.

\section{Analisis Indeks Jawaban}

Penelitian ini menggunakan teknik analisis indeks dengan menggambarkan responden atas beberapa item pertanyaan yang diajukan oleh peneliti. Teknik skoring menggunakan skor minimal 1 dan maksimal 4. Pemenuhan jawaban dari tiap pertanyaan per variabel persentasenya dapat ditunjukkan melalui nilai diatas. Sehingga skor tertinggi dalam penelitian ini adalah $100 \%$ dan skor terendah adalah 25\%. Bentuk persentase adalah dari 25 hingga nilai 100, dikarenakan skala 1-4 dikonversi 
dalam bentuk persentase. Sesuai kriteria tiga kotak (three box methods), jawaban dibagi menjadi tiga dan menghasilkan rentang nilai yang digunakan sebagai dasar interpretasi nilai indeks masing masing kelas dengan hasil sebagai berikut

$$
\begin{array}{ll}
25-50 & =\text { Kategori rendah } \\
51-75 & =\text { Kategori sedang } \\
76-100 & =\text { Kategori tinggi }
\end{array}
$$

Hasil pengukuran indeks jawaban variabel penelitian yang ditunjukkan tabel 1 menghasilkan kesimpulan bahwa seluruh variabel independen yaitu manfaat, kemudahan, keamanan, pengalaman, kompatibilitas berada pada kategori kelas tinggi.

\section{Hasil Pengujian Penelitian}

Penelitian ini telah melakukan pengujian variabel dengan menggunakan uji instrumen data berupa uji validitas dan reliabilitas serta uji asumsi klasik berupa uji normalitas, uji multikolinieritas dan uji heteroskedastisitas. Hasil pengujian dapat dilihat pada tabel 1 berikut:

Tabel 1. Hasil Uji Instrumen Data dan Asumsi Klasik Penelitian

\begin{tabular}{cccccc} 
& I & U & Uji & Uji & Uji \\
& n & ji & Re & Multi & Het \\
Vari & d & V & lia & koline & eros \\
abel & e & al & bili & aritas & ked \\
& k & id & tas & & asti \\
& s & it & & & sita \\
& as & & & s \\
\hline
\end{tabular}

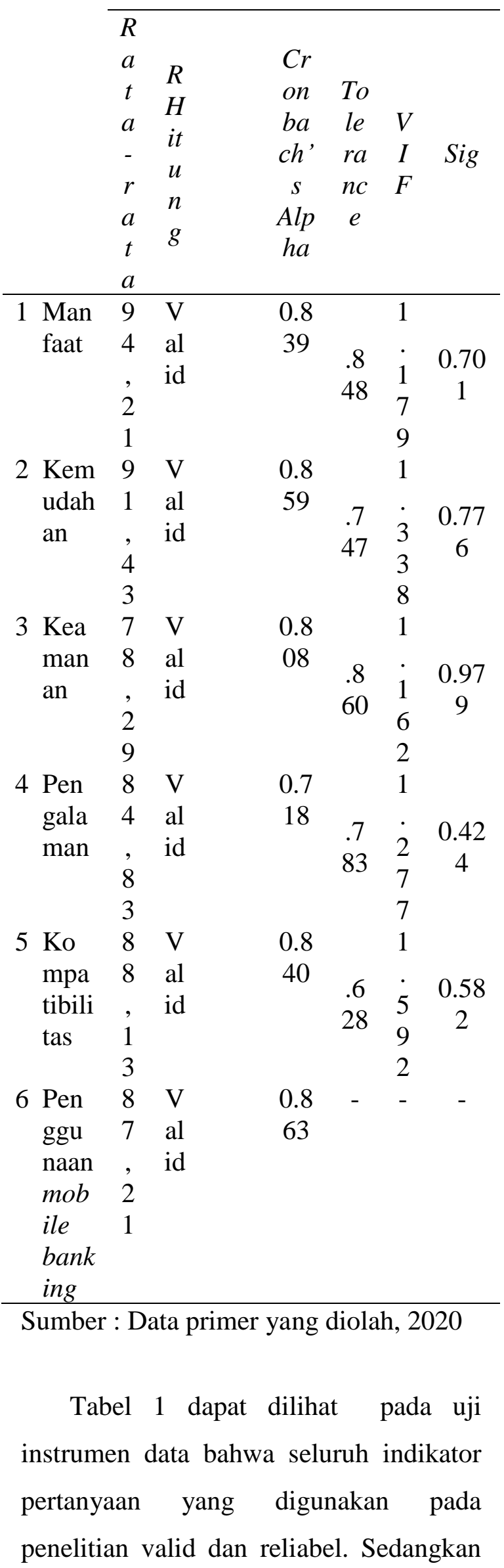


pada uji asumsi klasik menunjukkan data berdistribusi normal dan memenuhi syarat pengujian, sehingga dapat disimpulkan seluruh variabel lolos uji instrumen data dan uji asumsi klasik sehingga layak untuk diteliti.

\section{Analisis Regresi Linear Berganda}

Bentuk persamaan regresi yang dapat ditulis dari hasil uji kedalam bentuk persamaan regresi Standardized Coefficients Beta sebagai berikut:

Tabel 2. Hasil Uji Regresi Linear Berganda

\begin{tabular}{llccc}
\hline \multirow{2}{*}{ Model } & $\begin{array}{c}\text { Standardized } \\
\text { Coefficients }\end{array}$ & \multicolumn{2}{c}{$\begin{array}{c}\text { Uji t } \\
\text { (Parsial) }\end{array}$} \\
\cline { 3 - 5 } & Constant & B & T & Sig \\
\hline 1 & Manfaat & 0,341 & $-2,308$ & 0,023 \\
2 & Kemudahan & 0,192 & 2,479 & 0,000 \\
3 & Keamanan & 0,235 & 3,110 & 0,020 \\
4 & Pengalaman & 0,185 & 2,334 & 0,002 \\
5 & Kompatibilitas & 0,180 & 2,041 & 0,022 \\
6 & Kont
\end{tabular}

Sumber : Data Primer yang diolah, 2020

$\mathrm{Y}=0,341 \mathrm{X}_{1}+0,192 \mathrm{X}_{2}+0,235 \mathrm{X}_{3}$

$$
+0,185 \mathrm{X}_{4}+0,180 \mathrm{X}_{5}
$$

Keterangan :

$\mathrm{X}_{1}$ : Variabel Manfaat

$\mathrm{X}_{2}$ : Variabel Kemudahan

$\mathrm{X}_{3}$ : Variabel Keamanan

$\mathrm{X}_{4}$ : Variabel Pengalaman

$\mathrm{X}_{5}$ : Variabel kompatibilitas

Persamaan koefisen regresi di atas dapat disimpulkan sebagai berikut :

1. Koefisien regresi pada variabel manfaat $\left(\mathrm{X}_{1}\right)$ berpengaruh positif sebesar 0,341 yang artinya jika faktor manfaat terjadi peningkatan, maka tingkat penggunaan mobile banking akan meningkat, dengan asumsi variabel lain tetap (tidak berubah).
2. Koefisien regresi pada variabel kemudahan $\left(\mathrm{X}_{2}\right)$ berpengaruh positif sebesar 0,192 yang artinya jika faktor kemudahan terjadi peningkatan, maka tingkat penggunaan mobile banking akan meningkat, dengan asumsi variabel lain tetap (tidak berubah).

3. Koefisien regresi pada variabel keamanan $\left(\mathrm{X}_{3}\right)$ berpengaruh positif sebesar 0,235 yang artinya jika faktor keamanan terjadi peningkatan, maka tingkat penggunaan mobile banking akan meningkat, dengan asumsi variabel lain tetap (tidak berubah).

4. Koefisien regresi pada variabel pengalaman $\left(\mathrm{X}_{4}\right)$ berpengaruh positif sebesar 0,185 yang artinya jika faktor pengalaman terjadi peningkatan, 
maka tingkat penggunaan mobile banking akan meningkat, dengan asumsi variabel lain tetap (tidak berubah).

5. Koefisien regresi pada variabel kompatibilitas $\left(\mathrm{X}_{5}\right)$ berpengaruh positif sebesar 0,180 yang artinya jika faktor kompatibilitas terjadi peningkatan, maka tingkat penggunaan mobile banking akan meningkat, dengan asumsi variabel lain tetap (tidak berubah).

Tabel 2 secara parsial atau uji $\mathrm{t}$ menunjukkan bahwa semua hipotesis yang diterima karena memiliki pengaruh positif dan signifikan yaitu variabel manfaat, kemudahan, keamanan, pengalaman dan kompatibilitas, karena semua variabel memenuhi kriteria $t$ hitung > t tabel $(1,985)$ dan nilai sig < 0,05 .

\section{Uji Koefisien Determinan $\left(R^{2}\right)$}

Uji koefisien determinasi diperlukan untuk mengetahui seberapa besar kontribusi pengaruh variabel independen terhadap variabel dependen (Ghozali, 2006). Hasil pengujian koefisien determinan dapat dilihat pada tabel olah data model summary. Hasil pengujian memberikan kesimpulan bahwa nilai koefisien determinasi yang digunakan R Square model regresi sebesar 0,538, artinya variasi variabel manfaat, kemudahan, keamanan, pengalaman dan kompatibilitas mempengaruhi sebanyak $\quad 53,8 \%$ terhadap variabel penggunaan mobile banking. Sedangkan 46,2\% dipengaruhi variabel independen lain yang tidak terdapat pada penelitian ini.

\section{E. HASIL PEMBAHASAN}

\section{Pengaruh Manfaat Terhadap Penggunaan Mobile Banking}

Manfaat adalah suatu ukuran dimana penggunaan suatu teknologi dipercaya akan mendatangkan manfaat bagi orang yang menggunakannya. Kemampuan subjektif pengguna di masa yang akan datang di mana dengan menggunakan sistem aplikasi yang spesifik akan meningkatkan kinerja dalam konteks organisasi. Layanan mobile banking akan bermanfaat jika layanan tersebut mudah dimengerti serta mampu menjalin interaksi dengan penggunanya. Manfaat mobile banking haruslah memiliki ekuitas yang tinggi agar dapat menarik nasabah untuk menggunakan mobile banking. Hal ini disebabkan karna penggunaan mobile banking tidak hanya berasal dari kepribadian dan keiginan nasabah saja, namun dipengaruhi oleh keunggulan yang diberikan produk itu sendiri 
sehingga menarik perhatian nasabah yang mengetahuinya.

Penelitian kali ini menghasilkan bahwa pernyataan diatas terbukti benar jika manfaat merupakan salah satu aspek yang menjadi pertimbangan nasabah untuk menggunakan mobile banking. Dalam pencarian data lapangan disebutkan pada pertanyaan variabel manfaat di dalam indikator manfaat bahwa dengan menggunakan mobile banking akan meningkatkan kinerja nasabah dalam memanfaatkan layanan perbankan. Pernyataan ini tertuang pada point pertanyaan pertama dengan hasil uji validitas tertinggi pada indikator manfaat dengan $\mathrm{R}$ hitung sebesar 0.793 dan R tabel sebesar 0.195.

Hasil analisis deskriptif yang diberikan responden terhadap variabel manfaat memberikan penilaian yang sangat baik dengan hasil nilai rata rata indeksnya sebesar 92,25 dan termasuk kedalam kategori kelas "tinggi". Hal ini mencerminkan bahwa variabel manfaat menjadi salah satu aspek yang dapat mempengaruhi penggunaan mobile banking pada generasi milenial.

Analisis regresi yang telah dilakukan pada variabel manfaat menunjukkan hasil bahwa variabel manfaat berpengaruh secara positif dan signifikan terhadap variabel penggunaan mobile banking dengan nilai $\mathrm{t}$ hitung 4,479 lebih besar dari $\mathrm{T}$ tabel 1,985 dengan nilai signifikannya 0,000 . Oleh karena itu, pada hipotesis pertama (Ha1) Ho ditolak dan $\mathrm{Ha}$ diterima dengan kesimpulan variabel manfaat memiliki pengaruh positif terhadap penggunaan mobile banking pada generasi milenial.

Penelitian ini mengindikasikan bahwa semakin dirasakan manfaat dari penggunaan mobile banking, maka semakin meningkat minat seseorang untuk menggunakan mobile banking. Temuan dalam penelitian ini sesuai dengan konsep dari Davis (1989) yang mengkonsepkan bahwa persepsi manfaat diukur melalui indikator seperti meningkatkan kinerja pekerjaan, menjadikan pekerjaan lebih mudah serta secara keseluruhan teknologi yang digunakan dirasakan bermanfaat, sehingga persepsi kegunaan yang dirasakan dalam penggunaan mobile banking berpengaruh pada penggunaan mobile banking.

Hasil penelitian ini mendukung penelitian terdahulu oleh Lule (2012) dengan judul "Application Of Technology Acceptance Model In Mobile Banking Adoption In Kenya" yang menemukan bahwa Perceived Usefulness berpengaruh secara signifikan terhadap Penggunaan Mobile 
Banking. Begitu juga dengan penelitian yang dilakukan oleh Ahmad (2014) dan Rithmaya (2016) menunjukkan bahwa manfaat berpengaruh positif terhadap penggunaan mobile banking.

\section{Pengaruh Kemudahan Terhadap Penggunaan Mobile Banking}

Kemudahan penggunaan didefinisikan sebagai tingkat dimana seseorang meyakini bahwa penggunaan teknologi informasi merupakan hal yang mudah dan tidak memerlukan usaha keras dari pemakainya. Teknologi yang berkualitas yaitu teknologi yang mudah dalam penggunaannya. Namun, tidak hanya mudah dalam penggunaan dan pengoperasiannya, melainkan juga memudahkan pengguna menyelesaikan pekerjaan yang dilakukan dibandingkan tanpa menggunakan sebuah teknologi. Beberapa penelitian terdahulu juga menemukan bahwa saat ini aplikasi mobile banking mudah digunakan untuk melakukan kegiatan perbankan.

Penelitian kali ini menghasilkan bahwa pernyataan diatas terbukti benar jika kemudahan merupakan salah satu aspek yang menjadi pertimbangan nasabah untuk menggunakan mobile banking. Dalam pencarian data lapangan disebutkan pada pertanyaan variabel kemudahan dalam indikator kemudahan bahwa aplikasi mobile banking sangat jelas dan dapat dipahami oleh nasabah. Pernyataan ini tertuang pada point pertanyaan ketiga dengan hasil uji validitas tertinggi pada indikator kemudahan dengan $\mathrm{R}$ hitung sebesar 0.825 dan R tabel sebesar 0.195.

Hasil analisis deskriptif yang diberikan responden terhadap variabel kemudahan memberikan penilaian yang sangat baik dengan hasil nilai rata rata indeksnya sebesar 91 dan termasuk kedalam kategori kelas "tinggi”. Hal ini mencerminkan bahwa variabel kemudahan menjadi salah satu aspek yang dapat mempengaruhi penggunaan mobile banking pada generasi milenial.

Analisis regresi yang telah dilakukan pada variabel kemudahan menunjukkan hasil bahwa variabel kemudahan berpengaruh secara positif dan signifikan terhadap variabel penggunaan mobile banking dengan nilai t hitung 2,370 lebih besar dari $\mathrm{T}$ tabel 1,985 dengan nilai signifikannya 0,020. Oleh karena itu, pada hipotesis pertama (Ha1) Ho ditolak dan $\mathrm{Ha}$ diterima dengan kesimpulan variabel kemudahan memiliki pengaruh positif terhadap penggunaan mobile banking pada generasi milenial.

Hasil penelitian ini mendukung penelitian terdahulu oleh Hanif Astika Kurniawati, Wahyu Agus Winarno dan 
Alfi Arif (2017) tentang Analysis Behavioral Intention to Uses of Mobile Banking Technology Acceptance Model (TAM) Approach Modified yang menyatakan bahwa pengalaman, kompleksitas dan persepsi kemudahan berpengaruh terhadap minat perilaku pengguna mobile banking. Persepsi kemudahan berpengaruh terhadap minat perilaku pengguna mobile banking. Sulistiyarini (2016) dan Rian, dkk (2018) menunjukkan bahwa kemudahan berpengaruf positif terhadap minat penggunaan mobile banking.

\section{Pengaruh Keamanan Terhadap Penggunaan Mobile Banking}

Keamanan adalah suatu upaya untuk mengamankan aset informasi terhadap ancaman yang mungkin terjadi. Sehingga keamanan secara tidak langsung dapat mengurangi resiko resiko yang terjadi dan dapat menjamin kontinuitas bisnis. Tingkat keamanan bertransaksi secara online adalah permasalahan penting yang sering dipertimbangkan nasabah sebelum memutuskan untuk mengadopsi mobile banking. Beberapa nasabah beranggapan bahwa bertransaksi menggunakan mobile banking dapat menimbulkan resiko. Anggapan ini yang dapat merusak kepercayaan nasabah terhadap sistem online secara keseluruhan. Jika kebutuhan spesifik tentang keamanan belum terpenuhi, nasabah tidak akan siap merubah kebiasaan dari transaksi offline menjadi transaksi secara online. Oleh karena itu, langkah awal dalam menggunakan mobile banking yaitu identifikasi resiko yang potensial terjadi ketika menggunakan aplikasi mobile banking tersebut.

Penelitian kali ini menghasilkan bahwa pernyataan diatas terbukti benar jika keamanan merupakan salah satu aspek yang menjadi pertimbangan nasabah untuk menggunakan mobile banking. Dalam pencarian data lapangan disebutkan pada pertanyaan variabel keamanan dalam indikator keamanan bahwa nasabah yakin jika bank akan menjamin keamanan bertransaksi dengan menggunakan mobile banking. Pernyataan ini tertuang pada point pertanyaan kelima dengan hasil uji validitas tertinggi pada indikator keamanan dengan $\mathrm{R}$ hitung sebesar 0.810 dan R tabel sebesar 0.195.

Hasil analisis deskriptif yang diberikan responden terhadap variabel keamanan memberikan penilaian yang sangat baik dengan hasil nilai rata rata indeksnya sebesar 65,5 dan termasuk kedalam kategori kelas “sedang”. Hal ini mencerminkan bahwa variabel keamanan menjadi salah satu aspek yang 
dapat mempengaruhi penggunaan mobile banking pada generasi milenial.

Analisis regresi yang telah dilakukan pada variabel keamanan menunjukkan hasil bahwa variabel keamanan berpengaruh secara positif dan signifikan terhadap variabel penggunaan mobile banking dengan nilai t hitung 3,110 lebih besar dari $\mathrm{T}$ tabel 1,985 dengan nilai signifikannya 0,002 . Oleh karena itu, pada hipotesis pertama (Ha1) Ho ditolak dan $\mathrm{Ha}$ diterima dengan kesimpulan variabel keamanan memiliki pengaruh positif terhadap penggunaan mobile banking pada generasi milenial.

Hasil penelitian ini konsisten dengan penelitian Aviana Nur Aieni dan Anissa Hakim Purwantini (2017) tentang Eksplorasi Penggunaan Mobile Banking : Pendekatan Technology Acceptance Model yang menyatakan bahwa resiko mempunyai pengaruh terhadap penggunaan mobile banking. Penelitian lain yang dilakukan oleh Purwantini (2017) dan Ni Luh Putu (2017) menunjukkan bahwa keamanan berpengaruh positif signifikan terhadap minat penggunaan E-Banking.

\section{Pengaruh Pengalaman Terhadap Penggunaan Mobile Banking}

Pengalaman pengguna (User experience) merupakan persepsi atau tanggapan yang dihasilkan orang dari penggunaan dan atau antisipasi penggunaan suatu produk, sistem atau layanan. Pengalaman pengguna mencakup semua emosi, kepercayaan, preferensi, persepsi pengguna, perilaku, respons fisik dan psikologis dan pencapaian yang terjadi sebelum, selama, dan setelah digunakan. Pengalaman pengguna telah menjadi aspek kunci dalam desain produk dan jasa. Sebuah sistem informasi seharusnya tidak hanya bisa digunakan dan berguna, namun juga seharusnya dapat membuat pengguna nyaman untuk menggunakan sistem tersebut.

Penelitian kali ini menghasilkan bahwa pernyataan diatas terbukti benar jika pengalaman merupakan salah satu aspek yang menjadi pertimbangan nasabah untuk menggunakan mobile banking. Dalam pencarian data lapangan disebutkan pada pertanyaan variabel pengalaman dalam indikator pengalaman bahwa nasabah memiliki pengalaman yang baik terhadap mobile banking. Pernyataan ini tertuang pada point pertanyaan pertama dengan hasil uji validitas tertinggi pada indikator pengalaman dengan $\mathrm{R}$ hitung sebesar 0.810 dan $\mathrm{R}$ tabel sebesar 0.195 .

Hasil analisis deskriptif yang diberikan responden terhadap variabel 
pengalaman memberikan penilaian yang sangat baik dengan hasil nilai rata rata indeksnya sebesar 86,75 dan termasuk kedalam kategori kelas "tinggi". Hal ini mencerminkan bahwa variabel pengalaman menjadi salah satu aspek yang dapat mempengaruhi penggunaan mobile banking pada generasi milenial.

Analisis regresi yang telah dilakukan pada variabel pengalaman menunjukkan hasil bahwa variabel pengalaman berpengaruh secara positif dan signifikan terhadap variabel penggunaan mobile banking dengan nilai t hitung 2,334 lebih besar dari $\mathrm{T}$ tabel 1,985 dengan nilai signifikannya 0,022 . Oleh karena itu, pada hipotesis pertama (Ha1) Ho ditolak dan Ha diterima dengan kesimpulan variabel pengalaman memiliki pengaruh positif terhadap penggunaan mobile banking pada generasi milenial.

Hasil penelitian ini mendukung penelitian terdahulu oleh Hanif Astika Kurniawati, Wahyu Agus Winarno dan Alfi Arif (2017) tentang Analysis Behavioral Intention to Uses of Mobile Banking Technology Acceptance Model (TAM) Approach Modified yang menyatakan bahwa pengalaman, kompleksitas dan persepsi kemudahan berpengaruh terhadap kegunaan persepsian (perceived usefulness).
Pengalaman berpengaruh terhadap minat perilaku pengguna mobile banking. Penelitian lain yang dilakukan oleh Raka Yuwono Ario Wibowo, Satrio Hadi Wijoyo, Retno Indah Rokhmawati (2019) dan penelitian oleh Gardner (2004) menyatakan bahwa experience (pengalaman) berpengaruh positif signifikan terhadap penggunaan mobile banking.

\section{Pengaruh Kompatibilitas Terhadap Penggunaan Mobile Banking}

Kompatibilitas adalah tingkat sesuainya inovasi dengan nilai dan pengalaman perorangan. Tingkat keserasian dari suatu inovasi, apakah dianggap konsisten atau sesuai dengan nilai-nilai, pengalaman dan kebutuhan yang ada. Jika inovasi berlawanan dengan nilai-nilai dan norma yang dianut oleh adopter, maka inovasi baru tersebut tidak dapat diadopsi dengan mudah oleh adopter. Kompatibilitas termasuk dalam 20 teori difusi inovasi, di mana itu dianggap sebagai sejauh mana suatu inovasi cocok dengan nilai-nilai yang ada pada calon adopter, pengalaman sebelumnya dan kebutuhan saat ini. Hasil dari penelitian tersebut menyatakan bahwa kompatibilitas memiliki dampak positif dan signifikan dalam mempengaruhi pelanggan. 
Penelitian kali ini menghasilkan bahwa pernyataan diatas terbukti benar jika kompatibilitas merupakan salah satu aspek yang menjadi pertimbangan nasabah untuk menggunakan mobile banking. Dalam pencarian data lapangan disebutkan pada pertanyaan variabel kompatibilitas dalam indikator kompatibilitas bahwa sistem pada mobile banking cocok dengan gaya hidup nasabah saat ini. Pernyataan ini tertuang pada point pertanyaan ketiga dengan hasil uji validitas tertinggi pada indikator kompatibilitas dengan $\mathrm{R}$ hitung sebesar 0.876 dan R tabel sebesar 0.195.

Hasil analisis deskriptif yang diberikan responden terhadap variabel kompatibilitas memberikan penilaian yang sangat baik dengan hasil nilai rata rata indeksnya sebesar 88,75 dan termasuk kedalam kategori kelas "tinggi”. Hal ini mencerminkan bahwa variabel kompatibilitas menjadi salah satu aspek yang dapat mempengaruhi penggunaan mobile banking pada generasi milenial.

Analisis regresi yang telah dilakukan pada variabel kompatibilitas menunjukkan hasil bahwa variabel kompatibilitas berpengaruh secara positif dan signifikan terhadap variabel penggunaan mobile banking dengan nilai t hitung 2,041 lebih besar dari $\mathrm{T}$ tabel
1,985 dengan nilai signifikannya 0,044. Oleh karena itu, pada hipotesis pertama (Ha1) Ho ditolak dan $\mathrm{Ha}$ diterima dengan kesimpulan variabel kompatibilitas memiliki pengaruh positif terhadap penggunaan mobile banking pada generasi milenial.

Beberapa penelitian terdahulu juga menemukan bahwa saat ini aplikasi mobile banking mudah diterapkan dalam melakukan kegiatan perbankan. Hasil penelitian ini mendukung penelitian terdahulu oleh Yeong et al. (2015) tentang Network Externalities And The Perception Of Innovation Characteristics: Mobile Banking mengungkapkan bahwa ketika kompatibilitas meningkat, nasabah akan merasa lebih terdorong untuk menggunakan layanan mobile banking dan karenanya meningkatkan penggunaan. Hasil penelitian tersebut sama dengan hasil penelitian yang dilakukan oleh K. Erikkson, dkk (2008) dan Z. Islam, dkk (2013) yang menyatakan bahwa kompatibilitas berpengaruh positif signifikan terhadap niat penggunaan internet banking.

\section{F. KESIMPULAN}

Penelitian ini bertujuan untuk menganalisis penggunaan mobile banking pada generasi milenilal dengan 
menggunakan pendekatan Technology Acceptance Model (TAM). Kesimpulan berdasarkan hasil pembahasan penelitian ini adalah sebagai berikut:

1. Manfaat berpengaruh positif terhadap penggunaan mobile banking pada generasi milenial. Penelitian ini menemukan bahwa semakin seseorang merasakan manfaat atau kegunaan dari penggunaan mobile banking, maka semakin meningkat penggunaan mobile banking. Manfaat yang dirasakan generasi milenial dari penggunaan mobile banking yaitu dengan menggunakan mobile banking akan meningkatkan kinerja nasabah dalam memanfaatkan layanan perbankan.

2. Kemudahan berpengaruh positif terhadap penggunaan mobile banking pada generasi milenial. Penelitian ini mengindikasikan bahwa semakin seseorang percaya bahwa mobile banking mudah untuk digunakan, maka semakin meningkat penggunaan mobile banking. Kemudahan yang dirasakan generasi milenial dalam menggunakan mobile banking yaitu aplikasi mobile banking sangat jelas dan dapat dipahami oleh nasabah.
3. Keamanan berpengaruh positif terhadap penggunaan mobile banking pada generasi milenial. Penelitian ini menemukan bahwa ketika suatu teknologi, yang dalam penelitian ini yaitu mobile banking memiliki keamanan yang tinggi, maka akan meningkatkan kepercayaan seseorang dalam menggunakan mobile banking. Temuan dalam penelitian ini menunjukkan bahwa generasi milenial yakin jika bank akan menjamin keamanan bertransaksi dengan menggunakan mobile banking.

4. Pengalaman berpengaruh positif terhadap penggunaan mobile banking pada generasi milenial. Penelitian ini mengindikasikan bahwa semakin baik pengalaman seseorang dalam menggunakan mobile banking, maka penggunaan mobile banking akan semakin meningkat. Temuan dalam penelitian ini menunjukkan bahwa mayoritas generasi milenial memiliki pengalaman yang baik ketika menggunakan mobile banking.

5. Kompatibilitas berpengaruh positif terhadap penggunaan mobile banking pada generasi milenial. 
Penelitian ini menunjukkan bahwa semakin sesuai antara nilai-nilai, pengalaman dan kebutuhan seseorang dengan suatu teknologi, yang dalam penelitian ini yaitu mobile banking, maka penggunaan mobile banking akan meningkat. Temuan dalam penelitian ini menunjukkan bahwa sistem pada mobile banking cocok dengan gaya hidup nasabah saat ini. menggunakan mobile banking akan meningkat.

\section{Saran}

Dari hasil kesimpulan, maka peneliti memiliki saran yang perlu dipertimbangkan. Pertama, kepada pihak perbankan, peneliti menyarankan untuk meningkatkan sosialisasi mengenai manfaat, kemudahan dan keamanan dari mobile banking kepada nasabahnya agar pengguna mobile banking semakin meningkat. Kedua, kepada penelitian selanjutnya, diharapkan dapat meneliti dengan variabel independen yang lain dan responden yang lebih bervariasi. Sehingga data yang terhimpun lebih mewakili populasi yang ada.

\section{DAFTAR PUSTAKA}

Ariyanti, F. A. d. M. (2018). Analysis Of Factors Influencing Interest In Using Mobile Banking Application
On The Customer Bank BRI Purwakarta. e-Proceeding of Management Universitas Telkom, 5(2): 1584.

Center, A. R. (2017). The Urban Middle-Class Millenials Indonesia. Retrieved from http://alvarastrategic.com/wpcontent/uploads/whitepaper/TheUrban-Middle-Class-Millenials.pdf

David Kurniawan. (2013). Analisis Penerimaan Nasabah Terhadap Layanan Mobile Banking Dengan Menggunakan Pendekatan Technology Acceptance Model dan Theory Of Reasoned Action. Jurnal Strategi Pemasaran, 1(1): 13.

Davis, F. D. (1989). Perceived Usefulness, Perceived Ease of Use, and User Acceptance of Information Technology. MIS Quarterly, 13(5): 319-339.

Davis, M. (1986). A Technology of Acceptance Model for Empirically testing new-end user information system: Theory and Result. Massachusetts, USA: Sloan School of Management, Massachusets Institute of Technology.

Evi Yani, A. F. L. d. H. A. (2018). Pengaruh Internet Banking Terhadap Minat Nasabah Dalam Bertransaksi Dengan Technology Acceptance Model. Jurnal Informatika, 5(1): 34-42.

Fadhli, M. d. F., Rudy. (2016). Pengaruh Persepsi Nasabah Atas Risiko, Kepercayaan, Manfaat, Dan Kemudahan Penggunaan Terhadap Penggunaan Internet Banking (Studi Empiris Pada Nasabah Bank Umum Di Kota Banda Aceh). Jurnal Ilmiah Mahasiswa Ekonomi Akuntansi, 1(2): 264-276.

Farizi, H. d. S. (2013). Pengaruh Persepsi Kegunaan, Persepsi 
Kemudahan, Persepsi Resiko, dan Kepercayaan terhadap Minat menggunakan Internet Banking. Jurnal Akuntansi Universitas Brawijaya Malang.

Flight, R. L., D’Souza,G. and Allaway, Arthur W. (2011). Characteristicsbased innovation adoption: scale and model validation. Journal of Product and Brand Management, 20(5): 343355.

Gardner, C., dan D. L. Amoroso. (2004). Development of an instrument to measure the acceptance of internet technology by consumers. Paper read at System Sciences, 2004. Proceedings of the 37th Annual Hawaii International Conference on.

Gita, A. R. d. A. (2009). Pengaruh Inovasi Produk Terhadap Keputusan Pembelian Produk Audio Sony (Survei pada Konsumen di Toko Aneka Irama Jalan ABC Bandung). Jurnal Pendidikan Manajemen Bisnis, 8(16).

Gunawan, A. (2014). Aplikasi Technology Acceptance Model Pada Minat Nasabah Untuk Menggunakan Internet Banking Jurnal Nominal Volume Iii Nomor 2

Hanif Astika Kurniawati, W. A. W., Alfi Arif (2017). Analysis Behavioral Intention to Uses of Mobile Banking Technology Acceptance Model (TAM) Approach Modified. eJournal Ekonomi Bisnis dan Akuntansi, IV(1): 24-29.

Howe, W. S. a. N. (2000). Millennials Rising: The Next Great Generation. Cartoons by R.J. Matson. New York, NY: Vintage Original.

Indrawati, A. F. d. (2016). Influence Of Mobile Banking Service Quality To
Customer Satisfaction Bank BCA In Bandung. e-Proceeding of Management, 3(1): 2879.

Indriantoro, N. (2000). Pengaruh Comuter Anxiety Terhadap Keahlian Dosen dalam Menggunakan Komputer. JAAI, 4(2): 191-210.

Kim, S. H. (2008). Moderating Effects Of Job Relevance And Experience On Mobile Wireless Technology Acceptance: Adoption Of A Smartphone By Individuals. Information \& Management, 45(6): 387-393.

Kumar, A. A. L. (2008). Age Differences In Mbie Service Perceptions: Comparison Of Generaion Y And Baby Boomers. Journal Of Services Marketing, 22(7): 568-577.

Kupperschmidt, B. R. (2000). Multigenerational Employees: Strategies for Effective Management. The Health Care Manager, 19(1): 65-76.

Maharsi, S. (2007). Faktor-Faktor yang Mempengaruhi Minat Nasabah Menggunakan Internet Banking dengan Menggunakan Kerangka Technology Acceptance Model (TAM) Jurnal Akuntansi Dan Keuangan Universitas Kristen Petra, 9(1): 18-28. Retrieved from http://puslit.petra.ac.id/journals/acco unting

Maharsi, S. d. F. (2006). Analisa Faktorfaktor yang Mempengaruhi Kepercayaan dan Pengaruh Kepercayaan Terhadap Loyalitas Pengguna Mobile banking di Surabaya. Jurnal Akuntansi dan Keuangan, 8(1): 35-51.

Mannheim, K. (1952). The Problem of Generations. Essays on the 
Sociology of Knowledge, 24(19): 276-322-24.

Moeliono, N. P. W. d. N. N. K. (2017). Analisis Faktor-Faktor Penggunaan Layanan Mobile Banking Di Bandung. Bisnis Dan Iptek, 10(2): 141-142.

Page, W. d. (2011). Marketing To The Generations. Journal of Behavioral Studies In Business, 3(tn): 37 - 53.

Pambudi, A. d. B. S. (2014). Pengaruh Persepsi Manfaat, Persepsi Kemudahan, Keamanan Dan Ketersediaan Fitur Terhadap Minat Ulang Nasabah Bank Dalam Menggunakan Internet Banking (Studi Pada Program Layanan Internet Banking BRI). Jurnal Studi Manajemen, 8(1).

Rithmaya, C. L. (2016). Pengaruh Kemudahan Penggunaan, Kemanfaatan, Sikap, Risiko dan Fitur Layanan Terhadap Minat Ulang Nasabah Bank BCA Dalam Menggunakan Internet Banking. Jurnal Riset Ekonomi dan Manajemen, 16(1): 160-177.

Ryder, N. B. (1965). The Cohort as a Concept in the Study of Social Change. American Sociological Review, 30(6): 843-861. Retrieved from https://doi.org/10.2307/2090964
Suryani, T. (2013). Ilmu Perilaku Konsumen Di Era Internet. Yogyakarta: Graha Ilmu.

Syam, F. B. Z. (1999). Dampak Kompleksitas Teknologi Infoormasi Bagi Strategi Dan Kelangsungan Usaha. Jurnal Akuntansi Dan Auditing (JAAI), 3(1).

Vankatesh, V. M. e. a. (2003). User Acceptance of Information Technology: Toward a Unified View. MIS Quartely, 27(3): 425478.

Venkatesh, D. F. D. (2000). A Theoritical Extension of the Thechnlogy Acceptance Model: Fou Longitudinal Fild Studies. Managemen Sciences, 46(2): 186204.

Yousafzai, S. Y., Pallister, J. G., dan Foxall, G. R. (2003). A Proposed Model of $\mathrm{E}$ Trust for Electronic Banking. Technovation, 23(11): 847-860.

Pratiwi, D. P. (2012). Pengaruh Persepsi Manfaat, Persepsi Kemudahan Penggunaan dan Pengalaman Terhadap Perilaku Penggunaan MobileBanking Dengan Dimediasi Minat Penggunaan Mobile Banking Nasabah Bank BCA Di Surabaya. 